\title{
Increase in biodegradation of paclobutrazol in soils
}

\author{
Ednaldo Santos, Fernanda Vaz, Ester Gouvei \\ From 5th Congress of the Brazilian Biotechnology Society (SBBIOTEC) \\ Florianópolis, Brazil. 10-14 November 2013
}

\begin{abstract}
Background
Paclobutrazol is a regulator of vegetal growth that remains active in the soil and can affect the growth and the development of subsequent cultures. Experiments in two soils ( $A$ and $B$ ) with and without addition of inoculum or mineral medium were performed to investigate the biodegradation of paclobutrazol. The inoculum contained a mixed culture of three strains of bacteria isolated by enrichment and characterized as Pseudomonas. Flasks were incubated at ambient temperature, during 40 days. Paclobutrazol was quantified by high performance liquid chromatography. Addition of inoculum and mineral medium increased the biodegradation in both soils. The biodegradation ranged between 8 and 95\%. Higher biodegradation was obtained with addition of mineral medium, independently of soil utilized.
\end{abstract}

\section{Methodology}

Soil samples were collected at $0-20 \mathrm{~cm}$ depth in two areas (A and B) with irrigated mango plantation, with history of application, located in experimental stations of EMBRAPA (Empresa Brasileira de Pesquisa Agropecuária), in northeastern Brazil. Experiments, at ambient temperature during 40 days, with and without addition of inoculum or mineral medium were realized. The inoculum contained a mixed culture of three strains of bacteria isolated by enrichment and characterized as Pseudomonas. Control experiments also were performed. Paclobutrazol was quantified by high performance liquid chromatography using C-18 column, methanol:water (80:20) and $221 \mathrm{~nm}$.

\section{Results and conclusion}

In control experiments were obtained around $14 \%$ (A) and $8 \%$ (B) of degradation after 40 days. This reduction of paclobutrazol concentration was attributed at native

Universidade Federal de Pernambuco, Recife, PE, Brazil microbiota, since the soils had a history of application. After repeated applications of some pesticides, soil microorganisms become adapted to use the compound as carbon or energy source and they can grow on it [1]. In experiments with addition of inoculum, the biodegradation was $38 \%$ and $29 \%$, in soils A and B, respectively. Vaz et al. [2], found about $43 \%$ biodegradation, after 14 days, when added the same inoculum. Higher biodegradation observed by these authors was due to experiments to be in saturated soils. However, the results presented here were carried out in unsaturated soils. Low moisture content limits microbial growth and metabolism [3]. Furthermore, in experiments with addition of inoculum occurs loss of microbial viability during inoculation due to drastic changes in environmental conditions [4]. In experiments with addition of mineral medium, the biodegradation was around $95 \%$, independently of soil. In relation to control experiment, $579 \%$ and $1088 \%$ increase in biodegradation were obtained, in soil A and B, respectively. The increase in salt concentration led to a higher solubilization and consequently the improvement the biodegradation.

\section{Acknowledgements}

The authors acknowledge the financial support from Coordenação de Aperfeiçoamento de Pessoal de Nível Superior, Brasilia DF, Brazil (CAPES), and from Fundação de Amparo à Ciência e Tecnologia do Estado de Pernambuco (FACEPE). The Empresa Brasileira de Pesquisa Agropecuária (EMBRAPA) is thanked for donating the soil samples.

\section{Published: 1 October 2014}

\section{References}

1. Abdelrahman $\mathrm{H}$ : Biodegradation of some pesticides by soil microorganisms. Master thesis Zagazig University, Agricultural Botany Department; 2004.

2. Vaz FL, Netto AM, Antonino ACD, Gouveia ER, Martins JMF: Biodegradação de paclobutrazol por Pseudomonas spp. em sistemas de solo saturados. Química Nova 2012, 35:1090-1096.

3. Leahy JG, Colwell RR: Microbial-degradation of hydrocarbons in the environment. Microbiology and Molecular Biology Reviews 1990, 54:305-315. 
4. Vanveen JA, Vanoverbeek LS, Vanelsas JD: Fate and activity of microorganisms introduced into soil. Microbiology and Molecular Biology Reviews 1997, 61:121-135.

doi:10.1186/1753-6561-8-S4-P203

Cite this article as: Santos et al:: Increase in biodegradation of paclobutrazol in soils. BMC Proceedings 2014 8(Suppl 4):P203.

Submit your next manuscript to BioMed Central and take full advantage of:

- Convenient online submission

- Thorough peer review

- No space constraints or color figure charges

- Immediate publication on acceptance

- Inclusion in PubMed, CAS, Scopus and Google Scholar

- Research which is freely available for redistribution

Submit your manuscript at www.biomedcentral.com/submit

() BioMed Central 